\title{
Implementation of Vocational Learning in Improving Interest of Entrepreneurship, Student Work Practices in The Public Education Study Program
}

\author{
Fauzi Kurniawan ${ }^{1}$, Nurlaila ${ }^{2}$, Yasaratodo $\mathrm{Wau}^{3}$ \\ \{fauzi_k50@yahoo.com ${ }^{1 *}$, laila gayo@yahoo.co.id ${ }^{2}$,yasaratodo@gmail.com ${ }^{3}$ \} \\ ${ }^{1,2,3}$ Public Education Department, Universitas Negeri Mdan, Indonesia \\ *fauzi_k50@yahoo.com
}

\begin{abstract}
This research intend to know differences in student entrepreneurship interest in learning to use vocational learning with conventional for students of the Public Relations Department. Hypothesis testing uses t-test to test the differences between the control and experimental groups after the implementation of vocational learning, the N-Gain test sees the significance of improvement. Based on the Independent $t$ test, a significance value $(p$ $<0,05)$ was obtained, indicating there was a significant difference between the control and experimental classes. N-Gain Score is $0.4937(0.3<0.4937<0.7)$ so there is an effective level of understanding and the conclusion is there was a significant increase in interest after applying the vocational learning model. So using vocational learning model significantly higher than using conventional learning and increase in entrepreneurship interest in students is seen from the enthusiasm during the implementation of vocational learning and students begin to plan the form of entrepreneurship that is applied according their abilities
\end{abstract}

Keywords: learning model, vocational, interest in entrepreneurship

\section{Introduction}

Education has an important role in improving the quality of human resources owned. Efforts to improve the quality of education in accordance with the times and technology can improve Indonesia's dignity in the eyes of the world. One effort in improving the quality of education is to improve the quality of the learning process that can support the occurrence of an effective teaching and learning process and in accordance with the needs of students. The learning model must be well designed to obtain maximum learning outcomes adjusted to the learning needs and also the development of the times[1]. In the era of the development of the industrial revolution 4.0, the learning model must be able to improve one's expertise that can be applied in the world of work to be able to compete with other workers so that the vocational-based learning model is one of the appropriate choices. Vocational learning model is a learning model that emphasizes the process of providing assistance to individuals in the development of theory and practice with the aim of preparing individuals to be skilled in certain fields (in accordance with their talents, interests, and potential) in order to compete in the world of work, business and the industrial world that is carried out continuously [2]. A learning guide for students to be able to understand one particular subject that is designed is a vocational based learning model. In this case the subject that wants to develop the learning 
model to the fieldwork students which is a subject that focuses on the development between theory and practice so as to increase student interest in demonstrating vocational skills possessed in the community. Fieldwork is a course for students majoring in public education in $7^{\text {th }}$ semester. This course takes students to carry out learning theories while attending the college.

The learning model in fieldwork subjects is a vocational learning model that is useful as a provision that students will take when they go to the field, so that the vocational learning model that will be given is in the form of debriefing before participating in fieldwork activities, and when fieldwork is running students are required to be able to apply the vocational learning model that can be used in the field as an effort to educate the wider community as a target of community empowerment programs through street vendors. Students are required to have entrepreneurial skills that cover all aspects of work, both from traders, employers, private and government employees [3,4]. Creative efforts and innovation by developing ideas and gathering resources to find opportunities and improvements in life that called an entrepreneurship[5,6].

The purpose of this research was to determine the forms of the application of vocational learning models and their differences with conventional learning models in the fieldwork courses for 7 th semester students of the Department of Public Education.

\section{Research Methods}

This research is a quantitative study using the action research method with an emphasis on numerical. The subjects in this study were all students with registration number 2016 of Public Education Study Program who were taking part in fieldwork. Samples were taken by random sampling technique by taking 2 groups who participated in street vendors in the Tanjung Rejo Village and Binjai after being given treatment in each group.

The implementation variable in this study was the increase in students' interest in entrepreneurship after the application of the vocational learning model. Interest is measured using a pre-test questionnaire given before applying the model and post- test after applying the vocational learning model [7]. Data analysis uses normality test, homogeneity test and hypothesis test. The questionnaire was tested for validity on 64 students (correlation coefficient $\geq 0.32$ ) and its reliability test ( $\alpha$ cronbach $>0.83$ ).

\section{Results and Discussion}

The step taken is to compare the average learning outcomes between two groups, average post-test questionnaire from both groups. The average pre-test questionnaire with the post-test can be seen in the table 1 .

Based on table 2 the data in the independent sample $\mathrm{T}$ test obtained a significant value (2-tailed) 0,000, it means that there is a significant difference between the control class and the experimental class. This shows that there is a significant influence on the different treatments given to each class. So, it can be concluded that there are significant differences in the implementation of vocational learning models towards increasing entrepreneurial interest in fieldwork students of the Department of Public Education at Medan State University. 
Table 1. Summary of Research Results

\begin{tabular}{lccc}
\hline Class & \multicolumn{3}{c}{ Average of Pre-TestAverage of Post-TestIncreasing } \\
\hline Control & 95,67 & 98,22 & 2,55 \\
Experiment103,06 & 115,44 & 12,38 \\
\hline
\end{tabular}

Table 2. T Test Sample Results

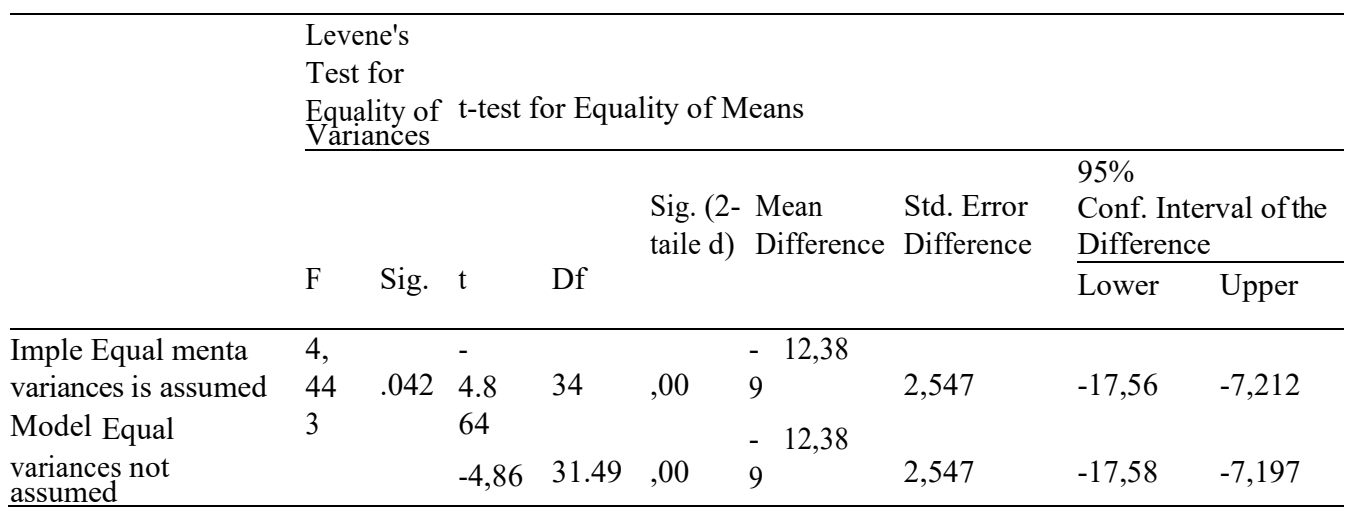

The learning model must be adapted to the learning needs so that learning goals can be achieved properly. Vocational learning models are provided to increase student entrepreneurial interest so as to increase willingness in entrepreneurship. Pre-test was carried out on both treatment groups using a questionnaire. This questionnaire is a closed questionnaire with four answer choices. The number of statements in the questionnaire was 33 statements.

After doing a pre-test, then the learning process is carried out with material skills to make souvenirs (key chains, hijab brooches, flowers, and flower vases) from acrylic material and make meatballs from milkfish. Learning in the treatment group uses the vocational learning model while learning in the comparison group only uses conventional learning models or does not add to the vocational learning model. The duration of learning time for the two groups is the same, namely 4 meetings for the material. The experimental group was given learning which directly practiced how to make souvenirs from acrylic material 3 times and made meatballs from milkfish 1 time. While in the control group when the learning process was not given direct practice, only given material on how to make souvenirs from acrylic and making meatballs from milk fish. What can be observed in this stage is that students in the experimental class are more enthusiastic about the skills material compared to students in the control class.

Similar to the pretest, the post-test in this study was also conducted on both treatment groups using a questionnaire. This questionnaire is in the form of a closed questionnaire with four answer choices. The number of statements in the questionnaire was 33 statements. The results of the post- test are then examined and a hypothesis test is conducted to draw a conclusion whether the vocational learning model can increase the interest of entrepreneurship in 7 th semester students who are taking the fieldwork course. 
Improved understanding of student learning outcomes can be interpreted using Normalized Gain (N-Gain). Improving the understanding of student learning outcomes in the learning process are not easy, using absolute gain (the difference between the initial test score and the final test) is less able to explain which are classified as high gain and which are classified as low gain. According to Hake, R. R. (2002 normalized gain (N-Gain) is formulated in the form of an equation as below:

$$
g=\frac{\text { skor posttest }- \text { skor pretest }}{\text { skor maksimal ideal }- \text { skor pretest }}
$$

The interpretation criteria are:

$\mathrm{g}$ - high if $\mathrm{g}>0.7$

$\mathrm{g}$ - moderate if $0.3<\mathrm{g} \leq 0.7 \mathrm{~g}$ - low if $\mathrm{g} \leq 0.3$

From the calculated N-Gain Score the following results are obtained:

Table 3. Results of Calculating the N-Gain Score

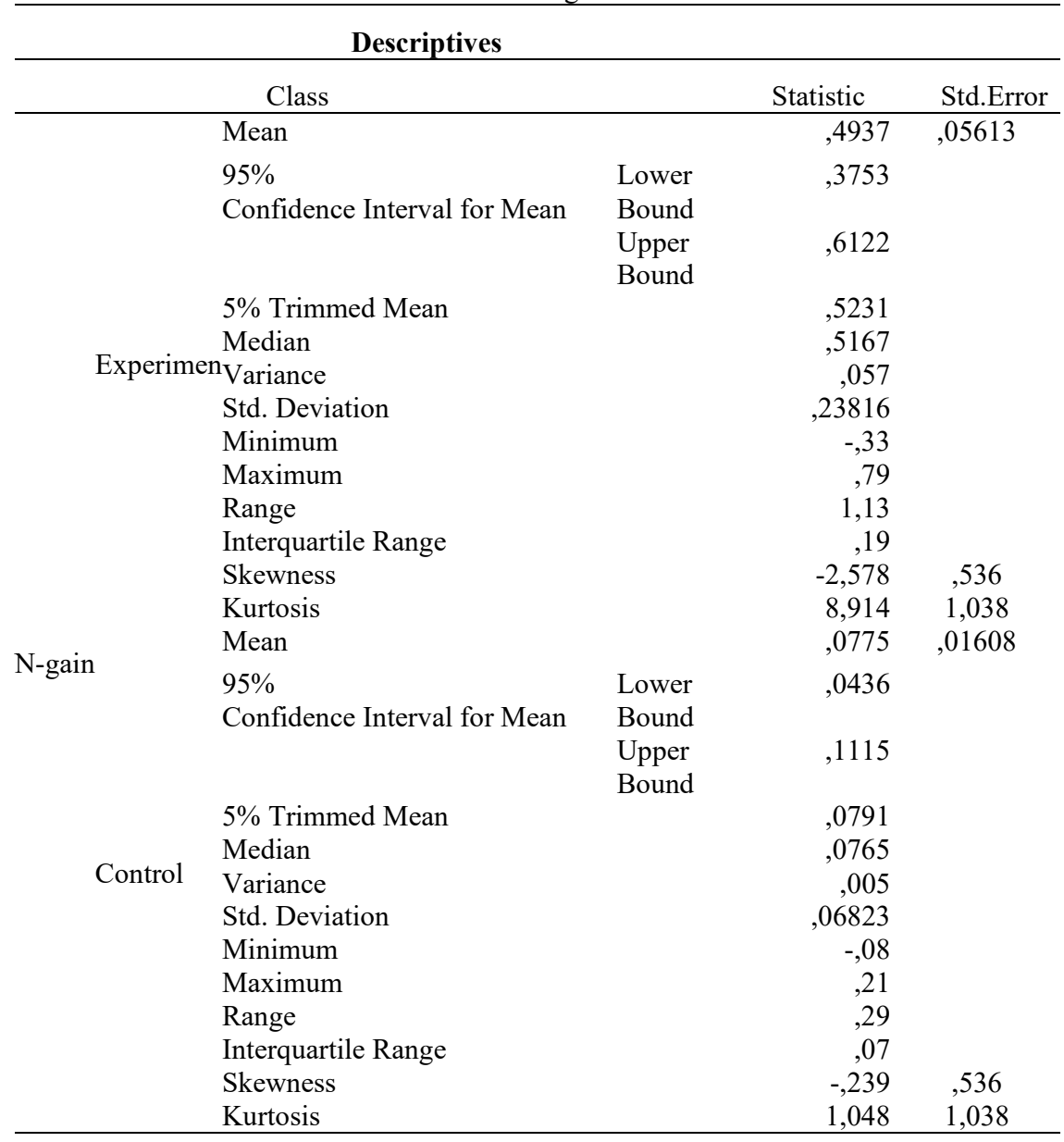


From the table above it is known that the value of the N-Gain Score is 0.4937 , where in this case it can be concluded that $0.3<0.4937<0.7$. So that there is an effective level of understanding by using a vocational learning model to increase student entrepreneurship interest in the Public Education Department in fieldwork subjects with a moderate degree of effectiveness.

\section{Conclusion}

Based on observations and tests during the study, findings on the implementation of learning, and analysis of student entrepreneurial interest before and after the application of vocational learning models for fieldwork courses for students of the Department of Public Education can be summarized as follows:

1) The ability of students to master the basic concepts of entrepreneurship and recognize the characteristics or character of entrepreneurs before learning is quite different, although it is less significant.

2) The ability of students to master the basic concepts of entrepreneurship and recognize the characteristics or character of people whose interest in entrepreneurship after learning has increased significantly and is different from before.

3) The enthusiasm and sincerity of students at street vendors when learning to use the vocational learning model is higher than students who take learning with conventional models.

The success in learning in the fieldwork courses using vocational learning models can be an alternative for designing and implementing good learning. Based on the results of this study, the suggestions that can be submitted are as follows:

1) With this research, it is expected that lecturers can use the vocational learning model to be applied to other lecture material related to the Application of Student Entrepreneurial Ability. The aim is to continue to motivate students to study because entrepreneurial lecture material has a very fundamental long- term impact especially for conducting research in the Public Education Department.

2) For lecturers, experimental research can provide stimulation to improve teaching competence of lecturers, especially in developing the application of learning approaches in the classroom.

3) For similar researchers, it is recommended that in conducting other studies pay more attention to the variables in research that are experimental and non-experimental. Nonexperimental variables tend to influence research results, for example: student learning environment, student learning facilities and infrastructure, lecturer competence in teaching, and student learning motivation. Should pay attention to things that can affect internal validity and as much as possible to control the control variables so that the results of the study can describe the results of the interventions provided and can improve further research. 


\section{References}

[1] Hake, R.R. Analyzing Change/Gain Score. Woodland Hills: Dept of Physics, Indiana University. [Online September 2019].http://www/physics.indiana.d u/ sdi/ Analyzing Change-Gain.pdf (1999).

[2] Ikhtiyarini, Pratina. Mengenal Pendidikan Vokasi. Jurnal Pewara Dinamika Universitas Negeri Yogyakarta. vol.14 No.62 (2013).

[3] Mardetini, Edutivia et. al. Peningkatan Pengetahuan dan Minat Berwirausaha Pada Industri Kreatif di Kecamatan Pemulutan Ogan Ilir. Jurnal Pemberdayaan Masyarakat Madani (JPMM). vol. 1, no. 2. (2017).

[4] Rosmiati et. al. Sikap, Motivasi, Dan Minat Berwirausaha Mahasiswa. Jurnal Manajemen dan Kewirausahaan. Politeknik Negeri Kupang. Vol. 17 No 1 (2015).

[5] Sagala, Syaiful. Konsep dan Makna Pembelajaran. Bandung: Alfabeta (2010).

[6] Sudira, Putu. Filosofi dan Teori Pendidikan Vokasi dan Kejuruan. Yogyakarta: UNY Press (2012).

[7] Sugiyono. Metode Penelitian Kombinasi. Bandung: Alfabeta (2017). 